\title{
The Sea Urchin Diadema antillarum (Echinodermata, Equinoidea), algal cover and juvenile coral densities in La Parguera, Puerto Rico
}

\author{
Francisco J. Soto-Santiago ${ }^{1}$ and Emmanuel Irizarry-Soto ${ }^{2}$ \\ 1. Department of Environmental Sciences, University of Puerto Rico, Río Piedras Campus, P.O. Box 70377, San Juan, P.R. 00936; \\ franciscoj_soto@yahoo.com \\ 2. Department of Biology, University of Puerto Rico, Cayey Campus, Ave. Antonio Barceló, Cayey, P.R. 00736
}

Received 18-IX-2012 Corrected 8-XI-2012 Accepted 16-I-2013

\begin{abstract}
Grazing by the black sea urchin Diadema antillarum reduces algal cover and enhances coral recruitment. The overall goal of this project was to examine if there is a relationship between densities of $D$. antillarum with algal cover and abundance of juvenile corals. Population densities of the black sea urchin, juvenile coral abundances and algal cover were assessed along four $20 \mathrm{~m}^{2}$ transects at two depth intervals $(0-3$ and 3-8m) within each of two inner shelf coral reefs off La Parguera Natural Reserve (San Cristóbal and Enrique) in southwest, Puerto Rico using a $1 \mathrm{~m}^{2}$ quadrat (divided into 100 areas of $100 \mathrm{~cm}^{2}$, each area encompassing $1 \%$ of the quadrat). Juvenile coral densities were counted and identified to genus or species. Algal cover and composition was measured using each $1 \%$ square of the $1 \mathrm{~m}^{2}$ quadrat. Urchin population densities were significantly higher at $0-3 \mathrm{~m}$ at the two sites studied. Population densities were higher at Enrique at $0-3 \mathrm{~m}$ than at San Cristobal but at $3-8 \mathrm{~m}$ Diadema was not seen at Enrique. A total of 30 juvenile corals belonging to eight different genera were found. Juvenile coral densities were higher at $3-8 m$ at the two reef sites studied. Algal cover and composition was mainly composed by crustose coralline algae at $0-3 \mathrm{~m}$ at both reef sites. Macroalgal cover was low at both reefs. The results of this study suggest that densities of coral recruits at inner shelf reefs in La Parguera, Puerto Rico are driven mainly by differences in habitats (depth).
\end{abstract}

\section{KEY WORDS}

Coral recruitment, abundance, Diadema antillarum, densities, composition, correlation.

\section{RESUMEN}

El pastoreo del erizo negro, Diadema antillarum reduce la cobertura de algas y provee sustrato disponible para el reclutamiento coralino. La meta principal de nuestro trabajo era examinar si existe una relación entre las densidades de $D$. antillarum, la cobertura de algas y el reclutamiento de corales. La densidad poblacional del $D$. antillarum, la abundancia de corales juveniles y la cobertura de algas fueron evaluados a lo largo de cuatro transectos de $20 \mathrm{~m}^{2}$, en dos intérvalos de profundidad (0-3m y 3-8m) en dos arrecifes de la zona interior de la Reserva Natural de La Parguera en el suroeste de Puerto Rico utilizando un cuadrante de $1 \mathrm{~m}^{2}$ (dividida en 100 áreas de $100 \mathrm{~cm}^{2}$, cada área abarcando $1 \%$ del cuadrante). La densidad de corales juveniles fue contada e identificada a género o especie. La cobertura y composición de algas fue medida utilizando cada cuadro pequeño representando $1 \%$ del cuadrante de $1 \mathrm{~m}^{2}$. La densidad poblacional de $D$. antillarum fue significativamente diferente en $0-3 \mathrm{~m}$ de profundidad en ambos lugares. Dichas densidades fueron más altas en Enrique en 0-3m de profundidad. Sin embargo en 3-8m no fueron encontrados los erizos en dicho arrecife. Un total de 30 corales juveniles pertenecientes a ocho géneros diferentes fueron encontrados. La densidad de los corales juveniles fue mayor en 3-8m en ambos lugares. La cobertura y composición de algas fue dominada por algas crustosas coralinas de $0-3 m$ en ambos arrecifes. La cobertura de macroalgas fue baja en ambos arrecifes. Nuestros resultados sugieren que las densidades de corales juveniles en arrecifes de la zona interior de La Parguera son guiados mayormente por diferencias en hábitats (profundidad).

\section{PALABRAS CLAVE}

Reclutamiento coralino, abundancia, Diadema antillarum, densidades, composición, correlación. 
One of the most studied grazers in coral reef ecosystems is the black sea urchin Diadema antillarum (Philippi, 1845). Diadema antillarum was distributed from the Gulf of Mexico, throughout the Caribbean, Surinam and Brazil in South America, northward to Bermuda and eastward to the Azores, Madeira and Cape Verde Islands and the Gulf of Guinea in western Africa (Carpenter, 1997; Atrill \& Kelmo, 2007). Diadema antillarum is omnivorous, preferring to feed on algal turfs but ingesting other sessile invertebrates (Randall, Schroeder \& Starck, 1964; Carpenter, 1981; Weil, Losada \& Bone, 1984). This urchin usually populates holes and crevices, emerging before sunset to forage during nighttime. Higher population densities used to be found in shallow depths (0-3m) (Randall et al., 1964; Vicente \& Goenaga, 1984; Carpenter, 1984, 1997; Weil et al., 1984, Weil, Torres \& Ashton, 2005; LugoAscorbe, 2004). Several small juveniles and species of fishes get shelter on the long spines of Diadema (Vicente \& Goenaga, 1984) as well as some invertebrates such as copepods, mysids, amphipods, shrimps, crabs (Randall et al., 1964) and larval stages of the Caribbean spiny lobster Panulirus argus (Vicente \& Goenaga, 1984). In 1983, a mass mortality caused by an unknown pathogen wiped out approximately $99 \%$ of D. antillarum in the wider Caribbean (Lessios, 1988). However, recent studies have suggested that two decades after the massive mortality, Diadema populations are slowly recovering (Carpenter \& Edmunds, 2006; Edmunds \& Carpenter, 2001; Weil et al., 2005; Martin-Blanco et al., 2010).

\section{Grazing by D. antillarum and coral recruitment}

Many studies have focused on the effects of grazing by $D$. antillarum on coral reef communities (Ogden et al., 1973; Sammarco, 1980, 1982; Carpenter, 1981, 1984, 1986, 1997; Hay, 1984; Foster, 1987; Hughes, Keller, Jackson \& Boyle, 1987; Hughes, 1989; Williams \& Carpenter, 1997; Edmunds \& Carpenter, 2001; Williams \& Polunin, 2001; Carpenter \& Edmunds, 2006; Furman \& Heck, 2009). The direct effects of grazing by $D$. antillarum are: (1) reduction of algal biomass, (2) enhancement of primary productivity rates on algal turf communities, (3) shifts of algal community composition and diversity, and (4) mortality of recruits and small juveniles of sessile marine invertebrates (Ogden et al., 1973; Sammarco, 1980; Carpenter, 1981, 1984, 1986, 1997; Foster, 1987; Hughes et al., 1987; Hughes, 1989 Williams \& Carpenter, 1997; Williams \& Polunin, 2001; Edmunds \& Carpenter, 2001; Carpenter \& Edmunds, 2006). After the mass mortality of Diadema in 1983, algal community structure on many affected reefs changed from algal turfs encompassed from many filamentous species and crustose coralline algae to a community dominated by macroalgal species (Lessios, 1988). Higher densities of Diadema are associated with a reduction in macroalgal cover and increased abundance of juvenile corals (Edmunds \& Carpenter, 2001; Myhre \& Acevedo-Gutiérrez, 2007). Sammarco (1980) suggested that high densities of Diadema could cause intense grazing, damaging juvenile corals and reducing coral recruitment, while in the absence of these sea urchins; corals could not compete with algae for substrate. As a result, intermediate densities of Diadema were suggested as best in regulating the abundances of corals and algae. Decreased survivorship of juvenile corals in the absence of grazing is due to overgrowth, shading and abrasion by macroalgae, smothering by sediment that accumulates on elevated algal biomass or a combination of these effects (Edmunds \& Carpenter, 2001).

Effects of grazing by $D$. antillarum on algal community structure have been studied in different sites in the wider Caribbean, Belize, Cuba, Panama, Grand Cayman and Jamaica, among others (Ogden et al., 1973; Sammarco, 1980, 1982; Foster, 1987; Edmunds \& Carpenter, 2001; Williams \& Polunin, 2001; Carpenter \& Edmunds, 2006). However, studies concerning $D$. antillarum in Puerto Rico have concentrated on determining their abundances, distribution, size structure, evaluation of potential interaction between the populations characteristics, spatial heterogeneity of various sites and habitats and evaluation of reproductive traits (Vicente \& Goenaga, 1984; Lugo-Ascorbe, 2004; Weil et al., 2005; Williams, García-Sais \& Capella, 2009; Williams \& García-Sais, 2010; Williams, Yoshioka \& García-Sais, 2010; Williams, García-Sais \&Yoshioka, 2011). However, none have assessed the potential relationship between the urchin densities and coral recruitment. Coral reefs in La Parguera encompass a substantial building block in the natural resources of Southwestern Puerto Rico. These reefs are extremely important for the local economy (i.e., tourism, commercial and recreational fishing activities) and because of the high biodiversity they sustain (Ballantine et al. 2008)

Studying the $D$. antillarum densities and exploring a potential co-variation with algal cover and juvenile coral abundances can help in the ongoing worldwide effort to increase our understanding about the process of herbivory in coral reef systems. The aim of this study is to determine if there is any relationship between $D$. antillarum population densities, algal cover and composition and juvenile coral abundances at two depth intervals $(0-3 ; 3-8 \mathrm{~m})$ at two fringing, inner shelf coral reefs in La Parguera, Puerto Rico. This will show at which depth (0-3m or 3-8m) Diadema can help in the regulation of these processes within each reef. 


\section{METHODOLOGY}

\section{Study site}

The south coast of Puerto Rico is characterized by lower wave energy and a wider insular shelf than the north coast (García, Morelock, Castro, Goenaga \& Hernández-Delgado, 2003). It also features embayments and submarine canyons (Acevedo \& Morelock, 1988). Fieldwork of this study was conducted in two coral reefs off La Parguera Natural Reserve, in the southwest coast of Puerto Rico. La Parguera is a dry and warm area with a yearly mean surface water temperature of $28,4^{\circ} \mathrm{C}$ (average maximum and minimum, $31,8^{\circ} \mathrm{C}$ and $22,5^{\circ} \mathrm{C}$ respectively) and the average surface salinity is 35,2 ppt (García, Schmitt, Heberer \& Winter, 1998). The insular shelf of La Parguera extends $8-10 \mathrm{~km}$ offshore. Abundant coral reefs and adjacent marine ecosystems such as seagrass beds dominated by Thalassia testudinum and mangrove forests dominated by Rhizophora mangle and fringe coral reefs encompass La Parguera. Reefs in La Parguera are aligned east to west and the insular shelf is divided into inner shelf, mid shelf and shelf edge reefs (García et al., 1998). Two inner shelf reefs were selected as the study areas: San Cristóbal Reef and Enrique Reef (Fig. 1). These sites were selected due to the abundance of Diadema in both sites (Lugo-Ascorbe, 2004; Weil et al., 2005). Furthermore, these two reefs have similar reef structure in both depth ranges analyzed.

Enrique Reef $\left(17^{\circ} 56,658 \mathrm{~N} ; 67^{\circ} 02,213 \mathrm{~W}\right)$ is a partially exposed fringing reef located $1,5 \mathrm{~km}$ off shore. The outer reef reaches a long shallow platform with mangrove keys and sea grass beds in an east-west direction. The reef platform is short (30-50m) with a $15 \mathrm{~m}$ drop and a community structure of corals and octocorals. San Cristóbal Reef $\left(17^{\circ} 56,450 \mathrm{~N} ; 67^{\circ} 04,659 \mathrm{~W}\right)$ is a partially exposed fringing reef, with an extended platform and a drop of $20 \mathrm{~m}$. It is located approximately $1 \mathrm{~km}$ off shore. Some species present are: Diploria clivosa, D. strigosa, D. labyrinthyformis, Acropora prolifera, Montastraea annularis, Porites astreoides and Favia fragum.

\section{Experimental design}

All the surveys were completed between August and December, 2009. Diadema antillarum individuals were counted within a $1 \mathrm{~m}^{2}$ quadrat along four transects parallel to shore $\left(20 \mathrm{~m}^{2}\right)$ on each depth intervals $(0-3$ and $3-8 \mathrm{~m})$.
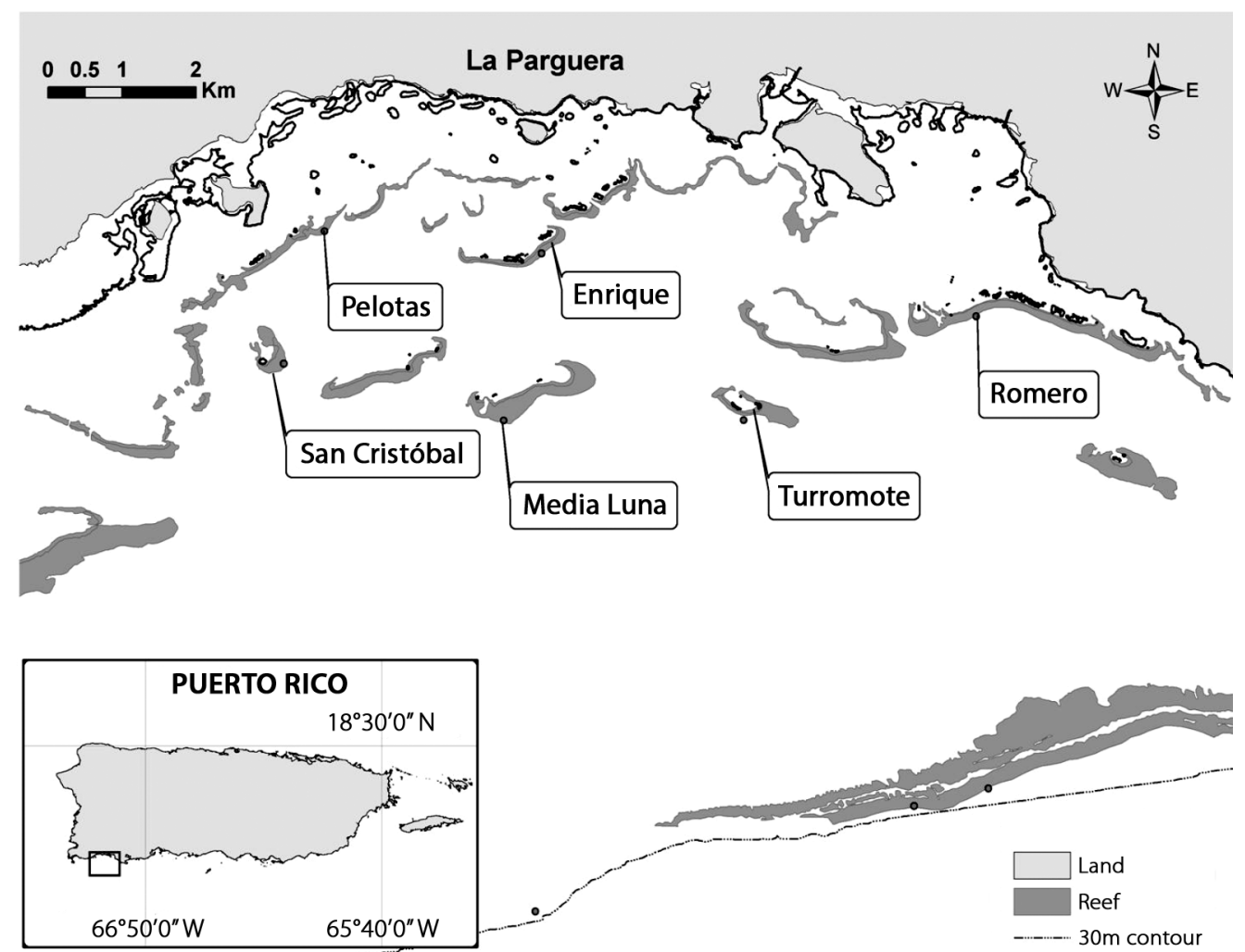

FIG. 1. Study sites at La Parguera, Puerto Rico. 
The quadrat was deployed randomly ten times along each of the four transects $(n=40)$ in each of the 2 depth intervals $(n=80)$ and used to estimate urchin densities. Urchins were counted in all places found (holes, rock crevices and pavement) during daylight.

Juvenile coral densities were measured using the same $1 \mathrm{~m}^{2}$ quadrat but divided it into 100 areas of $100 \mathrm{~cm}^{2}$, each area encompassing $1 \%$ of the sampling area. Depending on the species and its average size/area, a condition of minimum size was applied. For instance, colonies less than $5 \mathrm{~cm}$ in diameter for large-sized species (Montastraea spp., Colpophyllia natans, Diploria spp., etc.) and less than $2 \mathrm{~cm}$ for medium-small-sized colonies (Siderastrea spp., Porites spp., etc.) were considered juvenile corals not confusing this criterion with ramets resulting due to partial mortality of colonies. Percent algal cover (i.e., macroalgae, filamentous turf algae and crustose coralline algae or (CA) was determined by using the same $1 \mathrm{~m}^{2}$ quadrat used to collect juvenile coral densities.

Data did not fulfill the assumptions of parametric tests. A Permutational Analysis of Variance (PERMANOVA) was used to test differences on Diadema densities, juvenile coral densities and coral cover and composition between depth intervals and reef sites. PERMANOVA is a novel statistical approach for testing the concurrent response of one or more variables to one or more factors in an ANOVA experimental design of any distance measurement by using permutation methods (Anderson, 2001). Spearman's correlation analyses were used to look for relationships between algal cover and juvenile coral and D. antillarum densities.

\section{RESULTS}

\section{Diadema antillarum population densities}

Diadema antillarum population densities were significantly higher at $0-3 \mathrm{~m}$ than at 3-8m at the two sites studied (PERMANOVA; $p=0,0002$ ). Population densities were higher at Enrique at $0-3 m\left(2,35 \pm 0,63 \mathrm{ind} . / \mathrm{m}^{2}\right)$ than San Cristobal $\left(1,75 \pm 0,49 \mathrm{nd} . / \mathrm{m}^{2}\right)$ but at $3-8 \mathrm{~m}$ Diadema was not seen at Enrique (Fig. 2). However, significant differences between sites were not found (PERMANOVA; $p=0,2184$ ).

\section{Juvenile coral densities}

A total of 30 juvenile corals belonging to eight different genera were found. Juvenile coral densities were significantly higher at $3-8 \mathrm{~m}$ than at $0-3 \mathrm{~m}$ at the two sites studied (PERMANOVA; $p=0,0037)$. San Cristóbal showed higher juvenile coral densities at $3-8 \mathrm{~m}$ than at $0-3 \mathrm{~m}\left(0,35 \pm 0,04 \mathrm{col} . / \mathrm{m}^{2}\right.$ and $0,175 \pm 0,03 \mathrm{col} . / \mathrm{m}^{2}$ respectively). Same pattern was observed for Enrique $\left(0,075 \pm 0,03 \mathrm{col} . / \mathrm{m}^{2}\right.$ at $0-3 \mathrm{~m}$ and $0,225 \pm$ $0,03 \mathrm{col} . / \mathrm{m}^{2}$ at $3-8 \mathrm{~m}$ ) (Fig. 3).

Significant differences among juvenile coral densities were not found when comparing both sites (PERMANOVA; $p=0,2747)$. Siderastrea sp. and Montastraea sp. were the dominant scleractinian recruits between the two depths studied (Fig. 4).

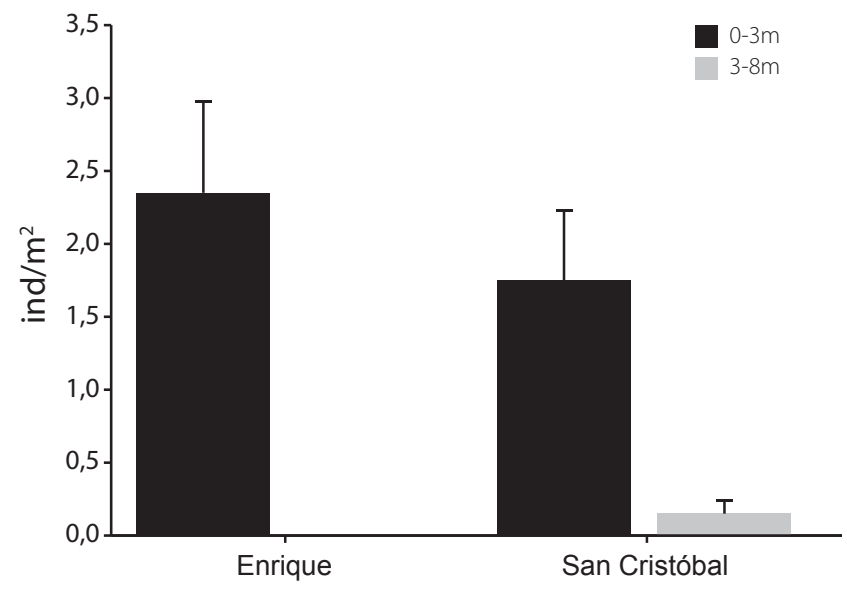

FIG. 2. Mean (+SE) of Diadema antillarum population densities at the two sites studied and depth intervals.

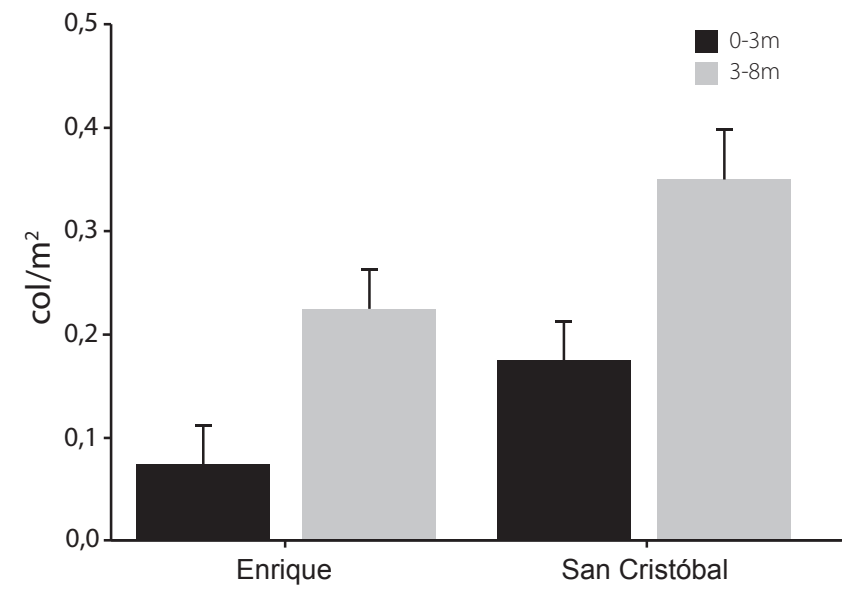

FIG. 3. Mean (+SE) juvenile coral densities at the two sites studied. 


\section{Algal cover and composition}

Algal cover and composition was mainly composed by crustose coralline algae (CCA) at $0-3 \mathrm{~m}$ and turf algae at $3-8 \mathrm{~m}$ within both sites (Fig. 5). Macroalgal cover was mainly composed of Dyctiota sp., Halimeda opuntia, $\mathrm{H}$. incrasata and Galaxaura sp. and was not significantly different when comparing sites (PERMANOVA; $\mathrm{p}=0,0610$ ) nor depths (PERMANOVA; $p=0,1070$ ). CCA (i.e. Porolithon sp.) showed significant differences between depths (PERMANOVA; $p=0.04$ ).

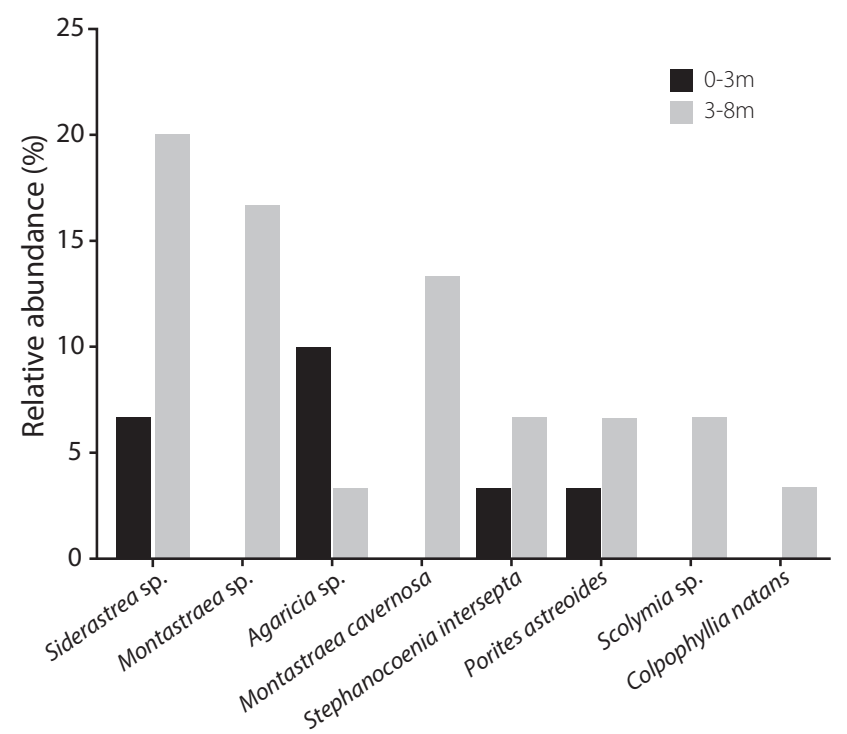

FIG. 4. Relative abundance (\%) of scleractinian recruits between the two depths studied.

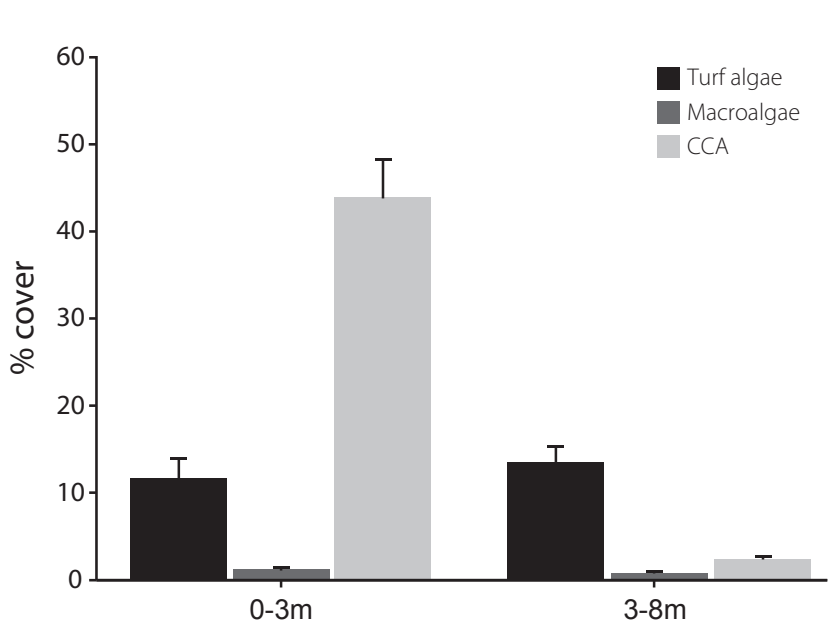

FIG. 5. Algal cover (\%mean \pm SE) between the two depths studied.

\section{Spearman's correlation analyses}

Correlation analysis between $D$. antillarum densities and juvenile coral densities were not significant at $0-3 \mathrm{~m}$ (Spearman's $R=0,05 ; p=0,60$ ) nor at 3-8m (Spearman's R=$0,03 ; p=0,75)$. However, a significant negative correlation was found when comparing $D$. antillarum densities and macroalgal cover at 0-3m (Fig. 6). Moreover, a significant positive correlation was found between $D$. antillarum densities and CCA cover at 0-3m (Fig. 7). Also, a significant negative correlation was found between $D$. antillarum densities and turf algae cover at 0-3m (Fig. 8).

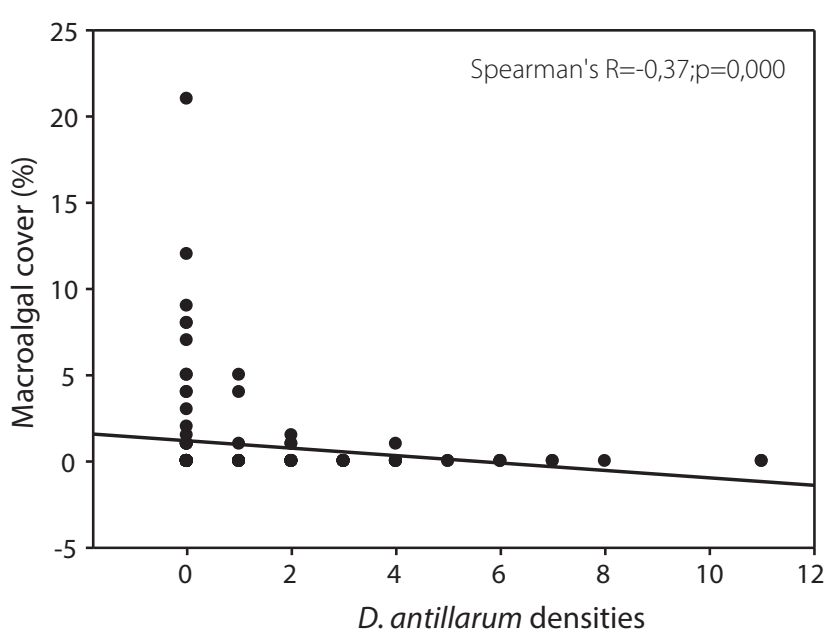

FIG. 6. Spearman's R correlation analysis between D. antillarum densities and macroalgal cover at 0-3m.

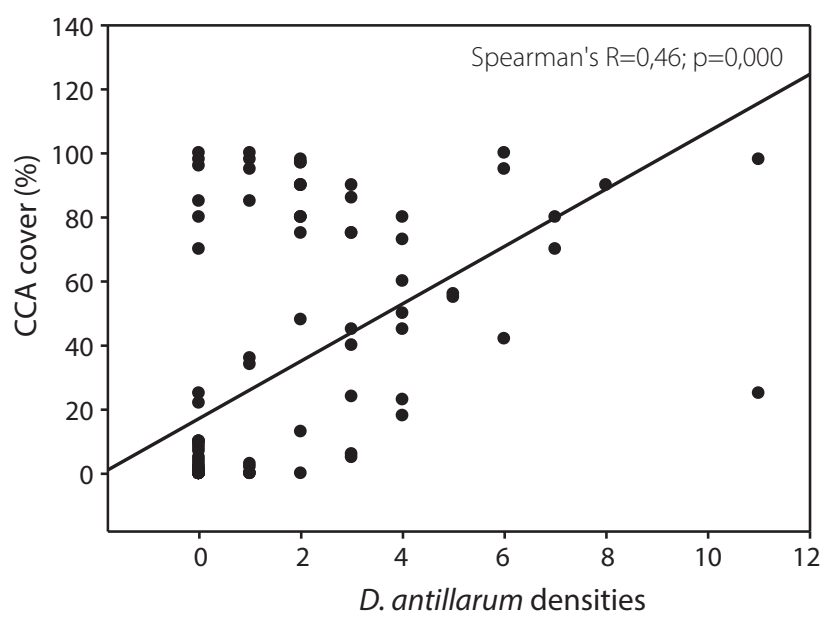

FIG. 7. Spearman's R correlation analysis between $D$. antillarum densities and CCA cover at 0-3m. 


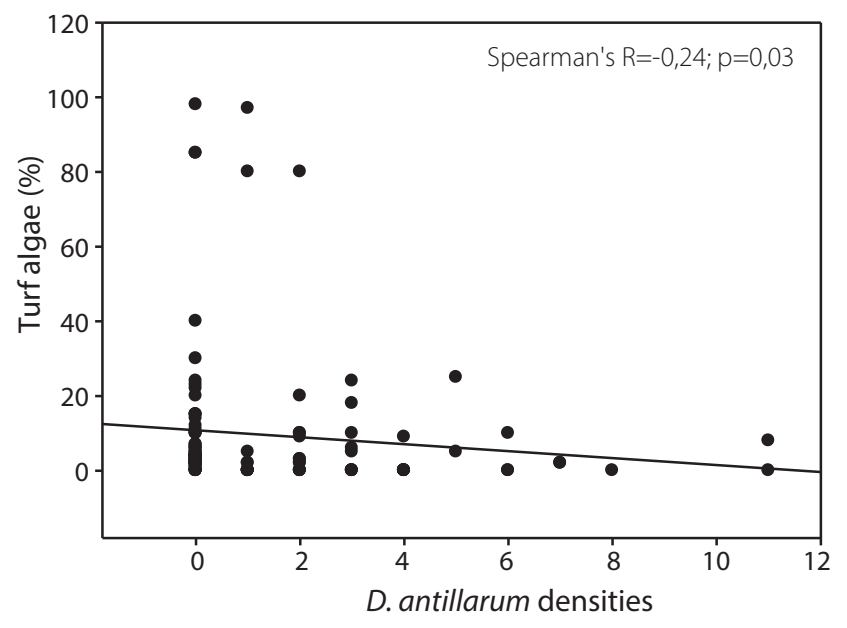

FIG. 8. Spearman's R correlation analysis between D. antillarum densities and turf algae cover at 0-3m.

\section{DISCUSSION}

Different studies have shown that $D$. antillarum can help in the regulation of coral reef communities (Ogden et al., 1973; Sammarco, 1980, 1982; Carpenter, 1981, 1984, 1986, 1997; Foster, 1987; Hughes et al. 1987; Hughes, 1989; Williams \& Carpenter, 1997; Edmunds \& Carpenter, 2001; Williams \& Polunin, 2001; Carpenter \& Edmunds, 2006). Moreover, it has been suggested that in some places in the Caribbean, Diadema densities can regulate the recruitment of corals by providing macroalgal free substrate so that coral recruits can settle faster (Edmunds \& Carpenter, 2001; Carpenter \& Edmunds, 2006).

The present study shows contrasting results within the two inner shelf reefs in La Parguera, Puerto Rico. This contrast is observed when comparing densities of Diadema and juvenile coral densities at the two depths studied. At $0-3 \mathrm{~m}$ Diadema densities (2,35ind./ $\mathrm{m}^{2}$ for Enrique and 1,75 ind./ $\mathrm{m}^{2}$ for San Cristóbal) were higher than 3-8m ( 0 for Enrique and 0,15ind./m2 for San Cristóbal) at both reefs. However, juvenile coral densities were higher at $3-8 \mathrm{~m}$ $\left(1,75 \mathrm{col} . / \mathrm{m}^{2}\right.$ for San Cristóbal and $0,225 \mathrm{col} . / \mathrm{m}^{2}$ for Enrique) at both reefs.

The positive but not significant relationship between D. antillarum densities and juvenile coral densities suggests that at both depths $(0-3 \mathrm{~m}$ and $3-8 \mathrm{~m})$ juvenile coral densities are driven by other ecological parameters and not by the presence or absence of $D$. antillarum. Other parameters that can affect coral recruitment can be depth, rugosity of the substrate, competition and local and regional atmospheric conditions (Irizarry-Soto, 2006). At $0-3 \mathrm{~m}$ in both reefs, the substrate was composed primarily of skeletons of Acropora palmata which was covered mainly by CCA. At this habitat (depth) we also found a significant positive correlation between CCA and D. antillarum densities. This is consistent with past studies that have suggested that Diadema foraging favors the growth of CCA and increases coral settlement (Edmunds \& Carpenter, 2001; Ruiz-Ramos et al., 2011). However, Agaricia $\mathrm{sp}$. was the only coral species to show higher juvenile coral densities at $0-3 m$ than $3-8 m$. This suggests that $D$. antillarum foraging may be favoring the settlement of only certain coral species at 0-3m. However, further research needs to be done to sustain this hypothesis.

At 3-8m at both sites, the substrate was mainly composed by turf algae (5,7 and 21,9\% for Enrique and San Cristóbal, respectively) although a zoanthid (e.g., Palythoa caribbaeorum) and adult scleractinians were the main competitors.

Macroalgal cover was low at both reefs. At 0-3m the significant negative correlation between macroalgal cover and urchin densities suggests that $D$. antillarum appears to control the abundances of this type of algae at this depth range. This finding concurs with past studies in the Caribbean (Edmunds \& Carpenter, 2001). However, our results on juvenile coral densities were lower at 0-3m than $3-8 \mathrm{~m}$. This means that competition for space by juvenile corals and macroalgae was not necessarily a factor driving the settlement of the juvenile scleractinian community at these inner shelf reefs. Diadema antillarum densities were not a factor either since higher juvenile coral densities were found at $3-8 \mathrm{~m}$ where none to low Diadema densities were found and no significant correlation found. In our study, higher diversity of juvenile corals were found in 3-8m, which is considered an intermediate depth range in these reefs (Irizarry-Soto, 2006). This concurs with past studies in La Parguera where the highest juvenile coral diversity was found at intermediate depths (Irizarry-Soto, 2006). Furthermore, the high abundance of the dominant juvenile scleractinians found in this study (Siderastrea sp. and Montastrea sp.) is consistent with past studies at inner shelf reefs in La Parguera (Irizarry-Soto, 2006). Moreover, this study showed that juvenile Montastraea sp. individuals are likely to be observed between 3-8m (intermediate habitats) under conditions that needs to be elucidated and may help to understand Montastraea sp. dynamics, especially when these species are now considered to be listed as endangered.

None to low juvenile coral densities at $0-3 \mathrm{~m}$ at both sites may be due to extreme wave action and to more vulnerability and exposure to hurricanes and storms which 
can affect the larval settlement. Also, highest densities of Diadema concentrating at $0-3 \mathrm{~m}$ at both sites may be a factor affecting coral recruits due to the intense grazing that these urchins can sustain (Sammarco, 1980). However, correlation between the two factors was not significant, probably due to the low numbers when entering juvenile coral densities in the equation. The significant negative correlation between Diadema densities and turf algal cover suggest that Diadema may be maintaining at a low cover the turf algae at $0-3 \mathrm{~m}$ by their intense grazing on this type of algae (Carpenter, 1986). Ruiz-Ramos and others (2011) mention that areas with higher abundance of corals provide higher refuge for urchins but less algae to feed on. In our study, higher abundance of corals (pers. obs.), none to low $D$. antillarum densities and higher juvenile coral densities were found at 3-8m.

Our results suggest that habitat (depth) may be driving juvenile coral densities at inner shelf coral reefs in La Parguera. At this depth coral recruitment is probably higher irrespective of the presence of $D$. antillarum. Further research needs to be done on other zones (mid shelf and shelf edge) in La Parguera to see if there is any relationship between $D$. antillarum densities and juvenile coral densities at different habitats (depths) and over time.

\section{ACKNOWLEDGEMENTS}

The authors thank Diana Beltrán and Stacy Williams for help in the field. Thanks to the employees of the Department of Marine Sciences, University of Puerto Rico at Mayaguez. Also, thanks to Ricardo Colón for help with the references.

\section{REFERENCES}

Attrill, M.J. \& Kelmo, F. (2007). Opportunistic responses of Diadema antillarum (Echinodermata: Echinoidea) populations following the 1997-98 El Niño event in Bahía, Brazil. Estuarine, Coastal and Shelf Science, 73, 243-248.

Acevedo, R. \& Morelock, J. (1988). Effects of terrigenous sediment influx on coral reef zonation in southwestern Puerto Rico. Proceedings of the 6th International Coral Reef Symposium, Australia, 2,189-194.

Anderson, M.J. (2001). A new method for non-parametric multivariate analysis of variance. Austral Ecology, 26: 32-46.

Carpenter, R.C. (1981). Grazing by Diadema antillarum (Philippi) and its effects on the benthic algal community. Journal of Marine Research, 39, 749-765.

Carpenter, R.C. (1984). Predator and population density control of homing behavior in the Caribbean echinoid Diadema antillarum. Marine Biology, 82, 101-108.
Carpenter R.C. (1986). Partitioning herbivory and its effect on coral reef algal communities. Ecological Monographs, 56, 345-363.

Carpenter, R.C. (1997). Invertebrate Predators and Grazers. In Birkeland, C (ed) Life and Death of Coral Reefs. (198-229). Chapman and Hall, New York, USA.

Carpenter, R.C. \& Edmunds, P.J. (2006). Local and regional scale recovery of Diadema promotes recruitment of scleractinian corals. Marine, 9(3), 271-280.

Edmunds, P.J. \& Carpenter, R.C. (2001). Recovery of Diadema leads to reduced macroalgal cover and increased abundance of juvenile corals on a Caribbean reef. Proceedings of the National Academy of Sciences, USA, 98, 5067-5071.

Furman, B. \& Heck, K.L.J. (2009). Differential impacts of echinoid grazers on coral recruitment. Bulletin of Marine Science 85(2), 121-132.

Foster, S.A. (1987). The relative impacts of grazing by Caribbean coral reef fishes and Diadema: effects of habitat surge. Journal of Experimental Marine Biology and Ecology, 105, 1-20.

García. J.R., Morelock, J., Castro, R., Goenaga, C. \& HernándezDelgado, E. (2003). Puertorican reefs: research synthesis, present threats and management perspectives. In Cortés, J.L. (ed), Latin American Coral Reefs (111-130). Elsevier: Amsterdam, The Netherlands.

García, J.R., Schmitt, C., Heberer, G. \& Winter, A. (1998). La Parguera, Puerto Rico UNESCO, CARICOMP-Caribbean coral reef, sea grass and mangrove sites. UNESCO: Paris, Francia.

Hay, M. (1984). Patterns of fish and urchin grazing on Caribbean coral reefs: are previous results typical? Ecology, 65(2), 446-454.

Hughes, T.P. (1989). Community structure and diversity of coral reefs: the role of history. Ecology, 70 (1), 275-279.

Hughes, T.P, Keller, B.D., Jackson, J.B.C, Boyle, M.J. (1987). Herbivory on coral reefs: community structure following mass mortality of sea urchins. Journal of Experimental Marine Biology and Ecology, 113, 39-59

Irizarry-Soto, E. (2006). Abundance, Composition, and Survivorship of Juvenile Corals in Southwestern Puerto Rico, La Parguera. (MS Thesis). University of Puerto Rico, Mayaguez, Puerto Rico.

Lessios, H.A. (1988). Mass mortality of Diadema antillarum in the Caribbean: What have we learned? Annual Review of Ecology and Systematics, 19, 371-393

Lugo-Ascorbe, M.A. (2004). Population status of the Black Sea Urchin Diadema antillarum (Philippi) in La Parguera, Puerto Rico, 20 years after the mass mortality event. (MS Thesis) University of Puerto Rico, Mayaguez, Puerto Rico.

Martín-Blanco, F., González-Sansón, G., Pina- Amargós, F. \& Clero-Alonso, L. (2010). Abundance, distribution and size structure of Diadema antillarum (Echinodermata: Diadematidae) in south eastern Cuban coral reefs. Revista de Biología Tropical 58(2): 663-676. 
Myhre, S. \& Acevedo-Gutiérrez, A. (2007). Recovery of sea urchin Diadema antillarum populations is correlated to increased coral and reduced macroalgal cover. Marine Ecology Progress Series, 329, 205-210.

Ogden, J.C, Brown, R.A. \& Salesky, N. (1973). Grazing by the Echinoid Diadema antillarum Philippi: Formation of Halos around West Indian Patch Reefs. Science, 182, 715-717.

Randall, J.E., Schroeder R.E. \& Starck II, W.A. (1964). Notes on the biology of the echinoid Diadema antillarum. Caribbean of Journal Science, 4, 421-433.

Ruiz-Ramos, D.V., Hernández-Delgado, E.A. \& Schizas, N.V. (2011). Population status of the Long Spined Urchin Diadema antillarum in Puerto Rico 20 years after a mass mortality event. Bulletin of Marine Science, 87(1), 113-127.

Sammarco, P. (1980). Diadema and its relationship to coral spat mortality: grazing, competition, and biological disturbance. Journal of Experimental Marine Biology and Ecology, 45, 245-272.

Sanmarco, P. (1982). Effects of grazing by Diadema antillarum (Philippi) (Echinodermata: Echinoidea) on algal diversity and community structure. Journal of Experimental Marine Biology and Ecology, 65, 83-105.

Vicente, V.P. \& Goenaga, C. (1984). Mortandades masivas del erizo de mar Diadema antillarum (Philippi) en Puerto Rico. Reporte CEER-M-195, Centro para Estudios Energéticos y Ambientales, Div. Ecología Marina, Univ. Puerto Rico, Puerto Rico.
Weil, E., Losada, F. \& Bone, D. (1984). Spatial variation in density and size of the echinoid Diadema antillarum Philippi on some Venezuelan coral reefs. Bijdragen tot de Dierkunde, 54(1), 73-84.

Weil, E., Torres, J.L. \& Ashton, M. (2005). Population characteristics of the sea urchin Diadema antillarum in La Parguera, Puerto Rico, 17 years after the mass mortality event. Revista de Biología Tropical, 53(3), 219-231.

Williams, I.D. \& Polunin, N.V.C. (2001). Large scale-associations between macroalgal cover and grazer biomass on mid depth reefs in the Caribbean. Coral Reefs, 19, 358-366.

Williams, S.L. \& Carpenter, R.C. (1997). Grazing effects on nitrogen fixation in coral reef algal turfs. Marine Biology, 130, 223-23.

Williams, S.M., García-Sais, J. \& Capella, J. (2009). Seasonal variation and spatial distribution patterns of early larval stages of the long-spined sea urchin Diadema antillarum in La Parguera, Puerto Rico. Caribbean Journal of Science, 45, 110-117.

Williams, S.M. \& García-Sais, J. (2010). Temporal and spatial distribution patterns of echinoderm larvae in La Parguera, Puerto Rico. Revista de Biología Tropical, 58, 81-88.

Williams S.M., Yoshioka, P.M. \& García-Sais, J. (2010). Settlement pattern of Diadema antillarum in La Parguera, Puerto Rico. Coral Reefs, 29, 809-812.

Williams S.M., García-Sais, J. \& Yoshioka, P.M. (2011) Spatial variation of Diadema antillarum settlement in La Parguera, Puerto Rico. Bulletin of Marine Science, 87, 531-540. 